\begin{tabular}{cc|c}
\hline Tar. Bil. Der. & Journal of Agricultural Sciences \\
& $\begin{array}{c}\text { Dergi web sayfası: } \\
\text { www.agri.ankara.edu.tr/dergi }\end{array}$ & Journal homepage: \\
& www.agri.ankara.edu.tr/journal
\end{tabular}

\title{
Determination of Nuclear DNA Content and Ploidy of Hypericum perforatum L. Accessions Collected from Western Turkey
}

\author{
Gülsemin SAVAŞ TUNA ${ }^{\mathrm{a}}$, Gözde DUYU ${ }^{\mathrm{a}}$, Kardelen UZUN ${ }^{\mathrm{a}}$, Gülru YÜCEL ${ }^{\mathrm{b}}$, Metin TUNA ${ }^{\mathrm{c}}$ \\ ${ }^{a}$ Ebru Nayim Science High School, 59030, Tekirdağ, TURKEY

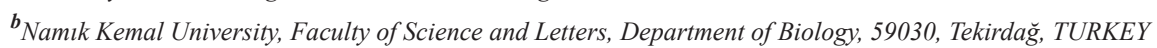 \\ ${ }^{c}$ Namık Kemal University, Faculty of Agriculture, Department of Field Crops, 59030, Tekirdağ, TURKEY
}

\section{ARTICLE INFO}

Research Article DOI: 10.15832/ankutbd.385863

Corresponding Author: Gülsemin SAVAk TUNA, E-mail: glsvs@yahoo.com, Tel: +90 (505) 2533430

Received: 21 September 2015, Received in Revised Form: 29 February 2016, Accepted: 16 March 2016

\begin{abstract}
Hypericum perforatum L. (St John's Wort) is a medicinal plant that produces pharmaceutically important compounds with antidepressive and anticancer activities. H. perforatum is a facultative apomictic species as it has the ability to reproduce with multiple reproduction mechanisms affecting genetic structure and chemical composition of the plants. The objective of this study was to determine nuclear DNA contents and ploidy levels of H. perforatum L. plants growing naturally in the flora of Turkey. The seeds of 39 Hypericum perforatum L. accessions collected from 23 different locations in Turkey were used in the study. Nuclear DNA contents of three different seedlings for each of the 39 $H$. perforatum accessions were determined using flow cytometry. Based on the results of flow cytometric analysis, nuclear DNA contents of the accessions varied between 0.8-2.57 $\mathrm{pg} \mathrm{2}^{-1}$. Nuclear DNA content differences observed among $H$. perforatum accessions were statistically significant $(\mathrm{P}<0.01)$ and the Duncan test revealed that the accessions formed three clearly distinguishable main groups. Mean nuclear DNA contents of each group were $0.80 \mathrm{pg} 2 \mathrm{C}^{-1}, 1.58 \mathrm{pg}$

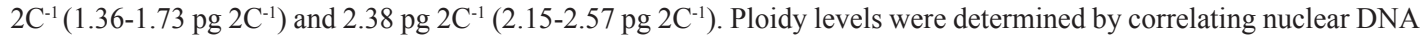
content of accessions with the number of their mitotic chromosomes by counting chromosome number of one plant from each group. Findings suggest that $H$. perforatum accessions used in this study had the following three different ploidy levels: diploid, tetraploid and hexaploid. The percentages of diploid, tetraploid and hexaploid accessions were 2.2, 86.4 and $11.4 \%$ respectively.
\end{abstract}

Keywords: Hypericum perforatum; Flow cytometry; Nuclear DNA content; Ploidy level; Medicinal plants

\section{Türkiye'nin Batı Bölgelerinden Toplanmış Hypericum perforatum L. Aksesyonlarının Çekirdek DNA İçerikleri ile Ploidi Düzeylerinin Belirlenmesi}

ESER BILGISII

Araştırma Makalesi

Sorumlu Yazar: Gülsemin SAVAŞ TUNA, E-posta: glsvs@yahoo.com, Tel: +90 (505) 2533430

Geliş Tarihi: 21 Eylül 2015, Düzeltmelerin Gelişi: 29 Şubat 2016, Kabul: 16 Mart 2016 


\section{ÖZET}

Hypericum perforatum L. (sarı kantaron) depresyon ve kanser gibi rahatsılıkların tedavisinde kullanılan, farmasötik açıdan önemli bileşikler üreten tıbbi bir bitkidir. H. perforatum, bitkilerin genetik yapısını ve kimyasal kompozisyonunu etkileyen birden fazla üreme mekanizması ile üreme yeteneğine sahip fakültatif apomiktik bir türdür. Bu çalışmanın amac1; Türkiye'nin doğal florasında bulunan H. perforatum L. aksesyonlarının çekirdek DNA içeriklerini ve ploidi düzeylerini belirlemektir. Çalışmada, Türkiye'nin 23 farklı lokasyonundan toplanan 39 Hypericum perforatum L. aksesyonuna ait tohumlar materyal olarak kullanılmıştır. Flow sitometri yöntemi ile H. perforatum aksesyonlarının herbiri için 3 farklı fide üzerinde çekirdek DNA analizi yapılmıştır. Flow sitometri analiz sonuçlarına göre aksesyonların


farklılıklar istatistiki açıdan $(\mathrm{P}<0.01)$ önemli iken Duncan testi sonuçlarına göre aksesyonlar 3 ana guruba ayrılmışlardır.

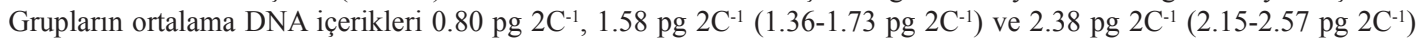
olarak belirlenmiştir. Aksesyonların ploidi düzeyleri her gruptan bir bitkinin kromozomlarını mikroskop ile sayarak DNA içeriği ile kromozom sayısını ilişkilendirmek suretiyle belirlenmiştir. Elde edilen bu sonuçlara göre H. perforatum aksesyonunlarının diploid, tetraploid ve hekzaploid olmak üzere 3 farklı ploidi düzeyine sahip oldukları tespit edilmiştir. Çalışmada incelenen akseyonların \% 2.2'sinin diploid, \% 86.4'ünün tetraploid ve \% 11.4'ünün hekzaploit olduğu görülmüştür.

Anahtar Kelimeler: Hypericum perforatum; Flow sitometri; Çekirdek DNA içeriği; Ploidi düzeyi; Tıbbi bitkiler

\section{Introduction}

Hypericum perforatum L., commonly known as St John's Wort, is a perennial medicinal plant that produces pharmaceutically important compounds with antidepressive, anticancer and antiviral activities (Gartner et al 2005; Barcaccia et al 2006). $H$. perforatum was originally native to Southern Europe, but today polyploids are also found in temperate regions of Northern Europe (Robson 1977; Qu et al 2010). H. perforatum is distributed throughout Turkey, occuring in open habitats and disturbed habitats along road sides (Davis 1988; Koch et al 2013). In addition to $H$. perforatum, 83 other Hypericum species are naturally growing in Turkey and 24 of them are considered endemic (Zeybek \& Zeybek 1994; Tokur 1988).

H. perforatum is assumed to be an allopolyploid and, based on morphological investigations and its geographical distribution, H. maculatum subsp. immaculatum and $H$. attenuatum are refered to as potential parents (Martonfi et al 1996; Robson 2002). The species is a facultative apomictic since sexual and aposporic processes can occur in the same plant. Reproduction in the species was investigated for the first time by Noack (1939) and the results of this study were confirmed and extended by Matzk et al (2001). Previous studies have shown that a normal reduced embryo sac occured only in 3\% of the ovules studied. In the majority of ovules (97\%) aposporous embryo sacs with 32 chromosomes were present. Although the egg cell is capable of parthenogenetic development, the polar nuclei must be fertilized (pseudogamy) (Martonfi et al 1996). These different types of reproduction mechanisms cause the occurrence of $H$. perforatum plants with different ploidy levels in natural populations. Those plants are impossible to differentiate based on their morphology. The amount of pharmaceutically important compounds also varies among plants within a natural population due to ploidy and genetic variation, and this leads to heterogeneity in the quality and bioactive components of $H$. perforatum preparations, since they are generally produced from wild plants. For example, diploid $H$. perforatum plants have more hypericin (an important pharmaceutical compound) compared to tetraploids (Cellarova et al 1997). H. perforatum products are generally standardized for their compounds to ensure phytochemical consistency. Controlled environment growth systems with genetically stable elite $H$. perforatum genotypes 
can provide a continuous supply of high quality plant materials with consistent levels of bioactive compounds (Alan et al 2015). Therefore, there is a growing demand to establish new collections of genetic resources for $H$. perforatum with distinct bioactive compounds. The ploidy levels of these newly collected genetic resources need to be determined before using them in breeding programmes to develop stable lines and cultivars. Ploidy analysis has not been done on $\mathrm{H}$. perforatum plants in Turkey prior to this study. The objective of this study was to determine ploidy levels of the H. perforatum accessions collected from different regions of Turkey for the first time.

\section{Material and Methods}

\subsection{Plant material}

The seeds of 39 Hypericum perforatum L. accessions from 23 different locations in mainly Western Turkey were used in the study (Table 1). The seeds were harvested from individual plants on July-September 2014, generally from along roadsides due to convenience.

\subsection{Germination of seeds}

Germination of $H$. perforatum seeds is problematic and the seeds need some specific treatments before planting. A germination procedure was used as previously described by Çırak et al (2004). In brief, the seeds were washed under running tap water for 10 minutes and then dried at room temperature. The dried seeds were kept in $50 \mathrm{mg} \mathrm{L}^{-1} \mathrm{GA}$ (gibberellic acid) exposed to light for 30 minutes before planting. In September (17.09.2014), the seeds were planted into multipots (a few seeds per hole) with sterile potting mix and left uncovered in order for them to receive sunlight. Only one plant was left in each hole by removing other seedlings after germination. Plants were irrigated from the bottom by adding water to trays placed underneath the multipots. Plants were grown in a plastic greenhouse with no environmental control systems, and maintained and monitored on a daily basis.

\subsection{Detection of nuclear DNA content}

Nuclear DNA content of the accessions was determined by the flow cytometry method. Suspensions of intact nuclei were prepared using commercial kits produced by Partec (Munster, Germany). Briefly, the procedure for nuclear DNA content analysis is as follows. Fresh leaf tissues of H. perforatum $(20 \mathrm{mg}$ ) and a standard (Vicia sativa, $40 \mathrm{mg}$ ) were simultaneously chopped in a petri dish with a $0.5 \mathrm{~mL}$ extraction buffer. The homogenized solution was transferred to a glass tube through a $33 \mu \mathrm{m}$ filter, and then $2 \mathrm{~mL}$ of staining buffer (CyStain PI absolute P) was added to each tube. The samples were incubated at room temperature in the dark for at least 30 minutes before analysis by the flow cytometer. Three seedlings were analysed individually for each accession and 5000 nuclei were analysed in each sample. Samples were run through a Partec CyFlow Space flow cytometer (Munster, Germany) and results were analysed by the FloMax analysis software program specifically designed for this cytometer.

Nuclear DNA content of $H$. perforatum seedlings was calculated based on relative positions of the G1 peaks of the sample and standard. Only results of samples that had a coefficient of variation (CV) less than $3 \%$ were used in the calculations. Standard deviation was calculated for the DNA content of each species using relevant measurements.

\subsection{Relating nuclear DNA content with ploidy of the accessions}

Nuclear DNA contents of the accessions were related with their ploidy by counting mitotic chromosomes of at least one seedling from each group. Root tips $(1-1.5 \mathrm{~cm})$ were harvested during early morning from adult plants growing in the greenhouse and treated with cold water for about 20 hours before fixation in farmer solution (3:1 Ethanol: Glacial acetic acid). Preparations were made following the classic feulgen procedure. Preparations were examined under a light microscope (Olympus BX51) and images of the cells with well-distributed mitotic chromosomes were taken using a CCD digital camera (Spot RT Slider) attached to the microscope. 
Table 1- Locations, code numbers, ploidy levels, nuclear DNA content, and significance groups of Hypericum perforatum $\mathrm{L}$. accessions

\begin{tabular}{|c|c|c|c|c|c|c|c|}
\hline $\begin{array}{l}\text { Accession } \\
\text { codes }\end{array}$ & Location & Latitude & Longitude & $\begin{array}{l}\text { Altitude } \\
\text { (m) }\end{array}$ & $\begin{array}{l}\text { Ploidy } \\
\text { level }\end{array}$ & $\begin{array}{l}\text { Nuclear } \\
\text { DNA } \\
\text { content } \\
\left.\text { (pg 2C } C^{-1}\right)\end{array}$ & $\begin{array}{l}\text { Significance } \\
\text { group }\end{array}$ \\
\hline İzm1a & 5 km. from Aliağa, İzmir & $38^{\circ} 46.338^{\prime}$ & $0.26^{\circ} 58.26^{\prime}$ & 2 & $\mathrm{D}$ & 0.80 & $\mathrm{a}$ \\
\hline Tek10a & Mahramlı Village Cemetery, Tekirdağ & $40^{\circ} 93.76^{\prime}$ & $027^{\circ} 19.50^{\prime}$ & 143 & $\mathrm{~T}$ & 1.36 & $\mathrm{~b}$ \\
\hline Tek13a & Uçmakdere Village, Tekirdağ & $40^{\circ} 79.96^{\prime}$ & $27^{\circ} 36.176^{\prime}$ & 180 & $\mathrm{~T}$ & 1.46 & $\mathrm{c}$ \\
\hline Smsn1 & 19 Mayıs University Faculty of Agriculture-Samsun & $41^{\circ} 36.87^{\prime}$ & $36^{\circ} 20.427^{\prime}$ & 140 & $\mathrm{~T}$ & 1.49 & $\mathrm{~cd}$ \\
\hline Edr4 & Bosna Village Road, Edirne & $41^{\circ} 39.46^{\prime}$ & $026^{\circ} 33.12^{\prime}$ & 205 & $\mathrm{~T}$ & 1.53 & cde \\
\hline Edr3 & Bosna Village Road, Edirne & $41^{\circ} 39.46^{\prime}$ & $026^{\circ} 33.12^{\prime}$ & 205 & $\mathrm{~T}$ & 1.53 & cde \\
\hline Tek14 & Namık Kemal University Campus, Tekirdağ & $40^{\circ} 99.02$ & $27^{\circ} 57.838^{\prime}$ & 21 & $\mathrm{~T}$ & 1.54 & $\mathrm{c}-\mathrm{f}$ \\
\hline Tek15 & Namık Kemal University Campus, Tekirdağ & $40^{\circ} 99.02$ & $27^{\circ} 57.838^{\prime}$ & 21 & $\mathrm{~T}$ & 1.54 & $c-g$ \\
\hline İzm2 & $5 \mathrm{~km}$. from Aliağa, İzmir & $38^{\circ} 46.338^{\prime}$ & $0.26^{\circ} 58.26^{\prime}$ & 2 & $\mathrm{~T}$ & 1.55 & c-g \\
\hline Tek12 & Uçmakdere Village, Tekirdağ & $40^{\circ} 79.96^{\prime}$ & $27^{\circ} 36.176^{\prime}$ & 180 & $\mathrm{~T}$ & 1.56 & d-g \\
\hline Tek3 & Sağlamtaş Village, Tekirdağ & $40^{\circ} 46.493$ & $027^{\circ} 04.558^{\prime}$ & 92 & $\mathrm{~T}$ & 1.56 & d-h \\
\hline Blk1 & Kaz Mountain slopes, Güre Village, Balıkesir & $39^{\circ} 36.50^{\prime}$ & $26^{\circ} 53.340^{\prime}$ & 165 & $\mathrm{~T}$ & 1.56 & d-h \\
\hline Kırk1 & Babaeski, Lüleburgaz, Kırklareli & $41^{\circ} 24.380^{\prime}$ & $0.27^{\circ} 16.01^{\prime}$ & 95 & $\mathrm{~T}$ & 1.57 & d-h \\
\hline Edr1 & Koru Mountain Keşan, Edirne & $40^{\circ} 42.951$ & $026^{\circ} 44.294^{\prime}$ & 240 & $\mathrm{~T}$ & 1.57 & d-h \\
\hline İst1 & Zeytinburnu Medicinal Plant Garden, İstanbul & $41^{\circ} 00.93^{\prime}$ & $28^{\circ} 91.609^{\prime}$ & 36 & $\mathrm{~T}$ & 1.57 & d-h \\
\hline Cnk2 & Ezine, Çanakkale, & $39^{\circ} 57.435^{\prime}$ & $0.26^{\circ} 17.58^{\prime}$ & 107 & $\mathrm{~T}$ & 1.58 & $e-i$ \\
\hline Kırk8 & Lüleburgaz, Çorlu, Kırklareli & $41^{\circ} 20.24^{\prime}$ & $027^{\circ} 28.059^{\prime}$ & 74 & $\mathrm{~T}$ & 1.58 & $e-i$ \\
\hline Kırk4 & Babaeski, Lüleburgaz, Kırklareli & $41^{\circ} 24.380^{\prime}$ & $0.27^{\circ} 16.01^{\prime}$ & 95 & $\mathrm{~T}$ & 1.58 & $e-i$ \\
\hline Kırk7 & Lüleburgaz, Çorlu, Kırklareli & $41^{\circ} 20.24^{\prime}$ & $027^{\circ} 28.059^{\prime}$ & 74 & $\mathrm{~T}$ & 1.58 & $e-i$ \\
\hline Tek6 & Karahisarlı Village Road, Tekirdağ & $40^{\circ} 57.625^{\prime}$ & $027^{\circ} 23.231^{\prime}$ & 271 & $\mathrm{~T}$ & 1.58 & $e-i$ \\
\hline Cnk1a & Ezine, Çanakkale, Çanakkale & $39^{\circ} 57.435^{\prime}$ & $0.26^{\circ} 17.58^{\prime}$ & 107 & $\mathrm{~T}$ & 1.58 & e-i \\
\hline Tek17 & Bahçeköy, Saray, Tekirdağ & $41^{\circ} 54.41^{\prime}$ & $28^{\circ} 04.418^{\prime}$ & 145 & $\mathrm{~T}$ & 1.58 & $e-i$ \\
\hline Tek16 & Yayabaşı Village, Tekirdağ & $40^{\circ} 93.66^{\prime}$ & $27^{\circ} 40.758^{\prime}$ & 117 & $\mathrm{~T}$ & 1.59 & $e-i$ \\
\hline Kırk9 & Lüleburgaz, Çorlu, Kırklareli & $41^{\circ} 20.24^{\prime}$ & $027^{\circ} 28.059^{\prime}$ & 74 & $\mathrm{~T}$ & 1.59 & $e-i$ \\
\hline Tek7 & Karahisarlı Village Road, Tekirdağ & $40^{\circ} 57.625^{\prime}$ & $027^{\circ} 23.231^{\prime}$ & 271 & $\mathrm{~T}$ & 1.59 & $e-i$ \\
\hline Tek9 & Muratl1, Tekirdağ & $41^{\circ} 07.021^{\prime}$ & $027^{\circ} 29.384^{\prime}$ & 140 & $\mathrm{~T}$ & 1.59 & $e-i$ \\
\hline Tek5 & Hayrabolu Road, Tekirdağ & $41^{\circ} 01.885^{\prime}$ & $027^{\circ} 46.088^{\prime}$ & 164 & $\mathrm{~T}$ & 1.61 & $e-i$ \\
\hline Kırk2 & Babaeski, Lüleburgaz, Kırklareli & $41^{\circ} 24.380^{\prime}$ & $0.27^{\circ} 16.01^{\prime}$ & 95 & $\mathrm{~T}$ & 1.62 & $e-i$ \\
\hline Kırk5 & Babaeski, Lüleburgaz, Kırklareli & $41^{\circ} 25.310^{\prime}$ & $027^{\circ} 08.967^{\prime}$ & 67 & $\mathrm{~T}$ & 1.62 & $e-i$ \\
\hline Kırk3 & Babaeski, Lüleburgaz, Kırklareli & $41^{\circ} 24.380^{\prime}$ & $0.27^{\circ} 16.01^{\prime}$ & 95 & $\mathrm{~T}$ & 1.62 & $e-i$ \\
\hline Kırk6 & Babaeski, Lüleburgaz, Kırklareli & $41^{\circ} 25.310^{\prime}$ & $027^{\circ} 08.967^{\prime}$ & 67 & $\mathrm{~T}$ & 1.62 & $e-i$ \\
\hline Edr2 & Havsa, Babaeski, Edirne & $41^{\circ} 28.40^{\prime}$ & $027^{\circ} 01.00^{\prime}$ & 89 & $\mathrm{~T}$ & 1.62 & $e-i$ \\
\hline Tek4 & Sağlamtaş Village, Tekirdağ & $40^{\circ} 46.519^{\prime}$ & $027^{\circ} 04.247^{\prime}$ & 96 & $\mathrm{~T}$ & 1.63 & $f-i$ \\
\hline Blk2 & Kaz Mountain slopes, Güre Village, Balıkesir & $39^{\circ} 36.50^{\prime}$ & $26^{\circ} 53.340^{\prime}$ & 165 & $\mathrm{~T}$ & 1.63 & $f-i$ \\
\hline Tek11 & Mahramlı Village Cemetery, Tekirdağ & $40^{\circ} 93.76^{\prime}$ & $027^{\circ} 19.50^{\prime}$ & 143 & $\mathrm{~T}$ & 1.63 & ghi \\
\hline Tek2b & İnecik, Arapac1, Tekirdağ & $40^{\circ} 51.145^{\prime}$ & $027^{\circ} 15.400^{\prime}$ & 304 & $\mathrm{~T}$ & 1.65 & hij \\
\hline Tek18 & Askerasıldı Site, Yeniköy, Tekirdağ & $40^{\circ} 64.31^{\prime}$ & $26^{\circ} 99.730^{\prime}$ & 219 & $\mathrm{~T}$ & 1.66 & $i-j$ \\
\hline Tek8 & Ayvasın Site, Uçmakdere, Tekirdağ & $40^{\circ} 79.374^{\prime}$ & $0.27^{\circ} 36.86^{\prime}$ & 600 & $\mathrm{~T}$ & 1.67 & $i-j$ \\
\hline Tek1 & İnecik, Arapac1, Tekirdağ & $40^{\circ} 51.145^{\prime}$ & $027^{\circ} 15.400^{\prime}$ & 304 & $\mathrm{~T}$ & 1.73 & $\mathrm{j}$ \\
\hline Tek10b & Mahramlı Village Cemetery, Tekirdağ & $40^{\circ} 93.76^{\prime}$ & $027^{\circ} 19.500^{\prime}$ & 143 & $\mathrm{H}$ & 2.15 & $\mathrm{k}$ \\
\hline Tek13b & Uçmakdere Village, Tekirdağ & $40^{\circ} 79.96^{\prime}$ & $27^{\circ} 36.176^{\prime}$ & 180 & $\mathrm{H}$ & 2.32 & 1 \\
\hline Cnk1b & Ezine, Çanakkale, Çanakkale & $39^{\circ} 57.435^{\prime}$ & $0.26^{\circ} 17.58^{\prime}$ & 107 & $\mathrm{H}$ & 2.43 & $\mathrm{~m}$ \\
\hline İzm1b & $5 \mathrm{~km}$. from Aliağa, İzmir & $38^{\circ} 46.338^{\prime}$ & $0.26^{\circ} 58.265^{\prime}$ & 2 & $\mathrm{H}$ & 2.49 & $\mathrm{mn}$ \\
\hline \multirow[t]{2}{*}{ Tek2a } & İnecik, Arapac1, Tekirdağ & $40^{\circ} 51.145^{\prime}$ & $027^{\circ} 15.400^{\prime}$ & 304 & $\mathrm{H}$ & 2.56 & $\mathrm{n}$ \\
\hline & & & & & & \multicolumn{2}{|c|}{ Mean square: 0.002} \\
\hline
\end{tabular}




\subsection{Statistical analysis}

In order to test statistical significance of differences among the nuclear DNA contents of accessions, variance analysis and the Duncan test were carried out using the GLM (General Linear Model) procedure in SAS. Correlation analysis was also conducted in order to determine the relationship between altitude and the nuclear DNA content. Regression analysis was used to determine to what extent the changes in altitude affected DNA content.

\section{Results and Discussion}

Ploidy analysis has traditionally been done by counting chromosomes in the meristematic cells of stained root tips, but the method is laborious, time consuming, and often difficult with species that have small chromosomes and high ploidy levels, which can lead to misclassification of germplasms (Tuna et al 2001). This method also requires a high number of dividing cells. The chromosomes are located in the nucleus of plant cells, enabling nuclear DNA content to be used as an estimate of ploidy level. Nuclear DNA content in plants was initially measured by Feulgen microspectrophotometry of mitotic root or shoot tip cells (Bennett \& Smith 1976); however, this method was slow and insensitive. In recent years, flow cytometry has become the preferred technique for estimating the nuclear DNA content in plants because of its simplicity, quickness, accuracy and relatively low cost (Heslop-Harrison 1995; Tuna et al 2001). Arumuganathan \& Earle (1991) determined nuclear DNA content of more than 100 major crop plant species using flow cytometry. Vogel et al (1999) used flow cytometry to determine base DNA content of the genomes in perennial Triticeae. Tuna et al $(2001 ; 2004)$ determined nuclear DNA content and ploidy of Bromus and Dactylis genetic resources.

The flow cytometer method was used to determine nuclear DNA content and ploidy of H. perforatum accessions in the study. Flow cytometric analyses of nuclei suspensions produced tall and sharp G1 peaks with CVs lower than $3 \%$ which indicates the precision of measurements (Figure 1,
2 and 3). Results of the nuclear DNA content analysis are presented in Table 1 and show that mean nuclear DNA content of accessions analysed in the study varied from $0.8 \mathrm{pg} 2 \mathrm{C}^{-1}$ to $2.57 \mathrm{pg}$ $2 \mathrm{C}^{-1}$. Nuclear DNA content differences observed among $H$. perforatum accessions were statistically very significant $(\mathrm{P}<0.01)$ and the Duncan test revealed that the populations formed three clearly distinguishable main groups (Table1). Mean nuclear

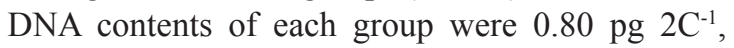

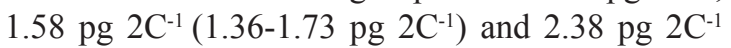
(2.15-2.57 pg $\left.2 \mathrm{C}^{-1}\right)$. The results obtained in the study were similar to previous studies (Brutovska et al 1998; Koch \& Sharbel 2011; Alan et al 2015). The slight differences among the results of current and previous studies might be because of the use of different $H$. perforatum accessions and internal standards (Dolezel \& Bartos 2005).

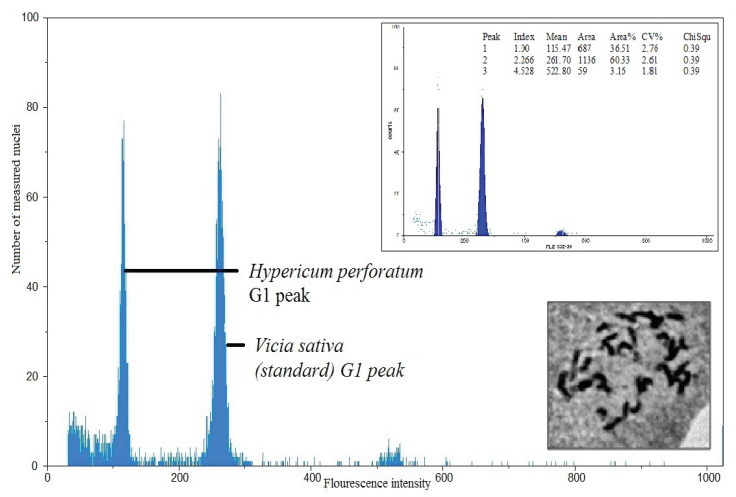

Figure 1- Relative positions of G1 peaks of tetraploid Hypericum perforatum (Cnk2) and standard (Vicia sativa), and mitotic chromosomes of tetraploid H. perforatum

When chromosomes of at least one of the seedlings from each main group were counted, it was found that acessions with an average of $1.58{\mathrm{pg} 2 \mathrm{C}^{-1}}^{-1}$ DNA content had $2 n=32$ chromosomes (tetraploid) (Figure 1) and accessions with an average of 2.38 pg $2 \mathrm{C}^{-1}$ DNA content had $2 \mathrm{n}=48$ chromosomes (hexaploid) (Figure 2). The cytological results of the study were also in agreement with results reported in earlier studies (Brutovska et al 1998; Koch \& 
Sharbel 2011; Alan et al 2015). Unfortunately, due to low mitotic index and a limited number of seedlings, it was not possible to count chromosome numbers in

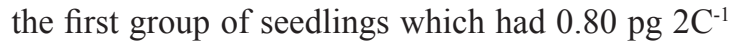
mean DNA content. However, according to results of previous studies, $H$. perforatum plants with $0.80 \mathrm{pg}$ $2 \mathrm{C}^{-1}$ mean DNA content have $2 \mathrm{n}=16$ chromosomes indicating that they are diploid (Figure 3). The wide nuclear DNA variation in the two groups with higher DNA content may be because of aneuploidy, which is a common phenomenon in polyploids. However, no attempt was made to count chromosomes of the seedlings with DNA content outside the typical range levels (seedlings with the lowest and highest DNA content compared to the group mean) for specific ploidy levels since it was out of the scope of this study. Important variation in nuclear DNA content within species is also generated by activity of transposable elements, length polymorphism in various repeat sequences, and genomic duplications causing the gain or loss of genetic material during the evolution of cytotypes (Vogel et al 1999; Tuna et al 2001; Greilhuber 2005; Gregory 2005; Smarda \& Bures 2010). According to the results of this study, seedlings obtained from the seeds of 34 of the accessions were tetraploids while the other five accessions consisted of seedlings varying in ploidy level. Seedlings of these five accessions were separated into two groups and codes of these accessions were labeled with letters ' $a$ ' and 'b' (e.g. İzmirla and İzmir1b). In such cases, three seedlings for each ploidy level from each of these specific accessions were analysed. Therefore, the number of accessions in Table 1 is 44 instead of 39.

In total, nuclear DNA content of 132 individual seedlings from 44 accessions were assessed in the study. When the results of the study were evaluated, it was found that the great majority of the individual seedlings $(86.4 \%)$ were tetraploid while $11.4 \%$ were hexaploid and $2.2 \%$ were diploid. The results of the current study corroborate the results of previous studies in this respect as well. For example, in their study involving individual plants from three different accessions, $\mathrm{Qu}$ et al (2010) reported that $85-91 \%$ of the seedlings were

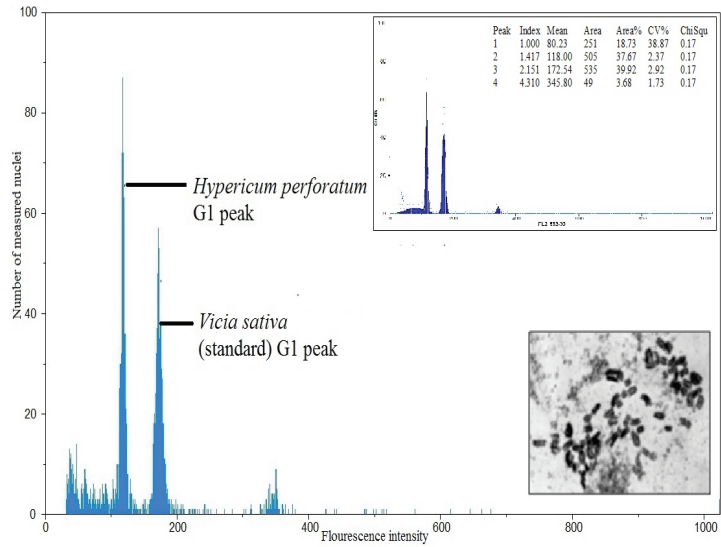

Figure 2- Relative positions of G1 peaks of hexaploid Hypericum perforatum (İzm1b) and standard (Vicia sativa), and mitotic chromosomes of hekzaploid H. perforatum

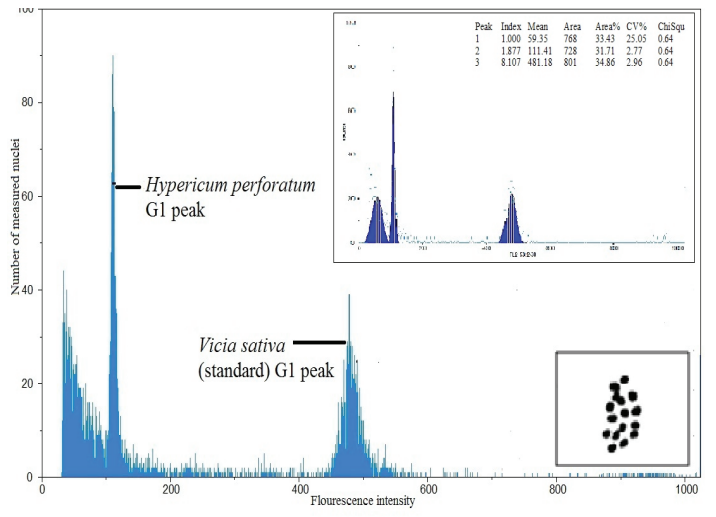

Figure 3- Relative positions of G1 peaks of diploid Hypericum perforatum (İzm1a) and standard (Vicia sativa), and mitotic chromosomes of diploid H. perforatum (chromosome photo, Nielsen 1924)

tetraploid, 9-14\% were hexaploid, and only one accession (5\%) was diploid. Koch \& Sharbel (2011) reported that $5.5 \%$ of 727 individuals studied (40 individuals) were diploid while the rest $(94.5 \%$, 687 individuals) were polyploid. Tetraploidy is by far the most common form found in the past and present studies which indicates that tetraploids may be the ancestral form (Qu et al 2010) and it is likely that they typically produce diploid cytotypes via 
haploid parthenogenesis and hexaploid cytotypes via fertilization of unreduced egg cells (Matzk et al 2001).

Based on results of the Duncan test, accessions were placed into one of the three groups (Table 1). Depending on results of the test, in some cases all accessions collected from the same location were grouped together (Kırk7, Kırk8, and Kırk9; Edr3 and Edr4) while in other cases not all accessions from the same location were grouped together (Tek12 and Tek14; Kırk1 and Kırk4; Blk1 and Blk 2). Accessions collected from remotely distant areas were also grouped together in some cases. For example, accessions collected from Tekirdă (Tek3), Balıkesir (Blk1), Kırklareli (Kırk1), Edirne (Edr1), and Istanbul (Ist1) were placed in the same group (Table 1). The results indicate that the geographical location of collections did not have an effect on nuclear DNA content variation observed among $H$. perforatum accessions. However, further study is recommended as the number of locations and accessions analysed in the study were quite limited. The effect of environmental conditions on nuclear DNA content is still under discussion since researchers have not yet reached an agreement on this issue. For example, results of some studies indicate that nuclear DNA content of some species are affected by environmental conditions (Cavallini et al 1993; Graham et al 1994; Singh et al 1996). But, the results of these studies were not confirmed when the same plant material was analysed by other researchers (Bennett et al 2000; Greilhuber 2005). However, the number of reports on intraspecific genome size variation is increasing due to improvements in variation detection methodology and the wide adoption of flow cytometry as a method for analysis (Smarda \& Bures 2010). Since 2005 , the existence of intraspecific variation and differences in genome size has been documented in a number of different plant species including Dasypyrum villosum (Greilhuber 2005), Romanian populations of Festuca (Smarda \& Bures 2006), Central European populations of Koeleria (Pecinka et al 2006), and wild wheat populations (Ozkan et al 2010).
In the current study, the effect of altitude on nuclear DNA content was investigated using a correlation analysis only on tetraploid accessions because there were not enough diploid and hexaploid seedlings to carry out the correlation analysis. The analysis revealed that there was a positive correlation between altitude and nuclear DNA content $\left(0.257^{* *}\right)$. This was considered statistically significant $(\mathrm{P}=0.006)$. Regression analysis was used to determine how the increase in altitude affected genome size. The regression equation was $y=242.1 x-235$ (Figure 4). Based on this analysis, a one-unit increase in altitude (x) caused a statistically significant increase in nuclear DNA content $(\mathrm{P}<0.01)$. The effect of altitude on nuclear DNA content was also observed by Reeves et al (1998) and Greilhuber (2005). For more robust conclusions about the correlation between altitude and nuclear DNA content of $H$. perforatum, further research is needed that includes improved methodology, larger sample sizes, and additional locations from more diverse regions.



Figure 4- Nuclear DNA content-altitude regression graph (pg 2C-1 DNA)

\section{Conclusions}

This study was the first attempt in Turkey to determine nuclear DNA content and ploidy level of the $H$. perforatum plants growing naturally in Turkish flora by flow cytometry. Flow cytometric analysis showed that the mean nuclear DNA 
contents of accessions analysed in the study varied from $0.8 \mathrm{pg} 2 \mathrm{C}^{-1}$ to $2.57 \mathrm{pg} 2 \mathrm{C}^{-1}$. The differences among accessions were statistically significant $(\mathrm{P}<0.01)$ as the Duncan test revealed that the accessions formed three clearly distinguishable main groups. The results indicate three ploidy levels (diploid, tetraploid, and hexaploid) present among H. perforatum accessions based on correlations among nuclear DNA content of accessions within each group and mitotic chromosome numbers determined by the classic method of counting chromosomes under a light microscope. The percentages of diploids, tetraploids and hexaploids were $2.2,86.4$ and 11.4, respectively. Tetraploids were by far the most common form of ploidy in Turkey, which indicates that tetraploids may be an ancestral form of $H$. perforatum. Furthermore, it is likely that tetraploid plants typically produce diploid cytotypes via haploid parthenogenesis and hexaploid cytotypes via fertilization of unreduced egg cells.

\section{References}

Alan A R, Murch S J \& Saxena P K (2015). Evaluation of ploidy variations in Hypericum perforatum L. (St. John's wort) germplasm from seeds, in vitro germplasm collection, and regenerants from floral cultures. In Vitro Cellular \& Developmental BiologyPlant 51: 452-462

Arumuganathan K \& Earle E D (1991). Estimation of nuclear DNA content of plants by flow cytometry. Plant Molecular Biology Reporter 9: 229-233

Barcaccia G, Arzenton F, Sharbel T F, Varotto S, Parrini P \& Lucchin M (2006). Genetic diversity and reproductive biology in ecotypes of the facultative apomict Hypericum perforatum L. Heredity 96: 322334

Bennett M D \& Smith J B (1976). Nuclear DNA amounts in angiosperms. Philosophical Transactions of the Royal Society of London B. 274: 227-274

Bennett M D, Johnston J S, Hodnett G L \& Price H J (2000). Allium cepa L. cultivars from four continents compared by flow cytometry show nuclear DNA constanc. Annals of Botany 85: 351-357

Brutovska R, Cellarova E \& Dolezel J (1998). Cytogenetic variability of in vitro regenerated Hypericum perforatum L. plants and their seed progenies. Plant Science 133: 221-229

Cavallini A, Lucia N, Cionini G \& Gennai D (1993). Nuclear DNA variability within Pisum sativum (Leguminosae): Nucleotypic effects on plant growth. Heredity 70: 561-565

Cellarova E, Bruňáková R, Bruňáková K, Daxnerová Z \& Weigel R C (1997). Correlation between hypericin content and the ploidy of somaclones of Hypericum perforatum L. Acta Biotechnologica 17: 83-90

Çırak C, Ayan A \& Kevseroğlu K (2004). The effects of light and some presoaking treatments on germination rate of St. John' worth (Hypericum perforatum L.) seeds. Pakistan Journal of Biological Sciences 7: 182-186

Davis P H (1988). Flora of Turkey and the East Aegean Islands. Edinburgh University Press, Edinburgh, UK

Dolezel J \& Bartos J (2005). Plant DNA flow cytometry and estimation of nuclear genome size. Annals of Botany 95: 99-110

Gartner M, Muller T, Simon J C, Giannis A \& Sleeman J P (2005). Aristoforin, a novel stable derivative of hyperforin, is a potent anticancer agent. Chembiochem 6: $171-177$

Graham N J, Nickell C D \& Rayburn A L (1994). Relationship between genome size and maturity group in soybean. Theoretical and Applied Genetics 88: $429-432$

Gregory T R (2005). The C-value enigma in plants and animals: A review of parallels and an appeal for partnership. Annals of Botany 95: 133-146

Greilhuber J (2005). Intraspecific variation in genome size in angiosperms: identifying its existence. Annals of Botany 95: 91-98

Heslop-Harrison J S (1995). Flow cytometry and genome analysis. Probe 5: 14-17

Koch M \& Sharbel T (2011). Evolutionary history of Hypericum perforatum L. PhD Thesis, RupertoCarola University, Germany

Koch M A, Scheriau C, Betzin A, Hohmann N \& Sharbel $\mathrm{T} F$ (2013). Evolution of cryptic gene pools in Hypericum perforatum: The influence of reproductive system and gene flow. Annals of Botany 111: 10831094

Martonfi P, Brutovska R, Cellarova E \& Repcak M (1996). Apomixis and hybridity in Hypericum perforatum. Folia Geobotanica Phytotaxonomy 31: 389-396 
Matzk F, Meister A, Brutovska R \& Schubert I (2001). Reconstruction of reproductive diversity in Hypericum perforatum L. opens novel strategiesto ménage apomixis. The Plant Journal 26: 275-282

Nielsen N (1924). Chromosome numbers in the genus Hypericum. Hereditas 5: 378-382

Noack K L (1939). Uber hypericum-kreuzungen VI. Fortpflanzungsver-haltnisse und bastarde von Hypericum perforatum L. Zeitschrift Induktive Abstammungsund Vererbungslehre 76: 569-601

Ozkan H, Tuna M, Kilian B, Mori N \& Ohta S (2010). Genome size variation in diploid and tetraploid wild wheats. AoB Plants plq015, doi: 10.1093/aobpla/ plq015

Pecinka A, Suchánková P, Lysak M A, Trávníček B \& Doležel J (2006). Nuclear DNA content variation among Central European Koeleria taxa. Annals of Botany 98: 117-122

Qu L, Widrlechner M P \& Rigby S M (2010). Analysis of breeding systems ploidy and the role of hexaploidsin three Hypericum perforatum L. populations. Industrial Crops and Products 32: 1-6

Reeves G, Francis D, Davies M S, Rogers H J \& Hodkinson T R (1998). Genome size is negatively correlated with altitude in natural populations of Dactylis polygama. Annals of Botany 82: 99-105

Robson N K B (1977). Studies in the genus Hypericum L. (Guttiferae) 1. Infrageneric classification. Bulletin of the British Museum Natural History Botany Series 5: 291-355
Robson N K B (2002). Studies in the genus Hypericum L. (Guttiferae) 4(2). Section 9. Hypericum senso lato (part 2): subsection 1. Hypericum series 1. Hypericum. Bulletins of the Natural History Museum: Botany Series 32: 61-123

Singh K P, Raina S N \& Singh A K (1996). Variation in chromosomal DNA associated with the evolution of Arachis species. Genome 39: 890-897

Smarda P S \& Bures P (2006). Intraspecific DNA content variability in Festuca pallens on different geographical scales and ploidy levels. Annals of Botany 98: 665-678

Smarda P \& Bures P (2010). Understanding intraspecific variation in genome size in plants. Preslia 82: 41-61

Tokur S (1988). Studies on the ecology of some Hypericum species. Turkish Journal of Botany 12: 323-331

Tuna M, Vogel K P, Arumuganathan K \& Kulvinder S G (2001). DNA content and ploidy determination of bromegrass germplasm accessions by flow cytometry. Crop Science 5: 1629-1634

Tuna M, Khadka D K \& Shrestha M K (2004). Characterization of natural orchardgrass (Dactylis glomerata L.) populations of the Thrace Region of Turkey based on ploidy and DNA polymorphisms. Euphytica 135: 39-46

Vogel K P, Arumuganathan K \& Jensen K B (1999). Nuclear DNA content of perennial grasses of the Triticeae. Crop Science 39: 661-667

Zeybek N \& Zeybek U (1994). Pharmaceutical Botany. Egean University Press. No: 2, İzmir, Turkey 